УдК 616.37-002.4-06:616.37-006.2:612.015.11

DOI 10.11603/2414-4533.2021.4.12617

(ОВ. В. БОЙКО, А. О. МЕРКУЛОВ ${ }^{1}$, К. М. ЯЦЬКО ${ }^{1}$, Є. О. БІЛОДІД', Н. В. БАЦМАН

Державна установа "Інститут загальної та невідкладної хірургії імені В. Т. Зайцева НАМН України"

Харківський національний медичний університет ${ }^{2}$

Харківська медична академія післядипломної освіти ${ }^{3}$

\title{
Аналіз стану процесів ліпопероксидації залежно від сформованості постнекротичної кісти підшлункової залози
}

\begin{abstract}
Мета роботи: дослідити вміст псевдокіст підшлункової залози із подальшим аналізом стану вільнорадикальних процесів, що відбуваються.

Матеріали і методи. Представлено дані аналізу обстеження 62 хворих із псевдокістами підшлункової залози. Вивчено прооксидантно-антиоксидантний баланс у крові, а також у вмісті псевдокіст підшлункової залози залежно від ступеня сформованості кістозної стінки.

Результати досліджень та їх обговорення. Дослідження вмісту псевдокіст підшлункової залози дало змогу проаналізувати стан вільнорадикальних процесів, що відбуваються, і виявило високу токсичність ексудату при несформованих псевдокістах. Маркером несформованості стінки псевдокісти є підвищений вміст малонового діальдегіду в еритроцитах крові хворих.
\end{abstract}

Ключові слова: панкреонекроз; псевдокіста підшлункової залози; ліпопероксидація.

Постановка проблеми і аналіз останніх досліджень та публікацій. Формування псевдокісти підшлункової залози, можливо, є наслідком недостатньо активного або несвоєчасного лікування гострого панкреатиту. Причиною цього може бути й глибинне ураження паренхіми підшлункової залози. Утворення постнекротичної кісти підшлункової залози завжди $є$ наслідком деструкції тканини підшлункової залози. При набряковій формі гострого панкреатиту псевдокісти підшлункової залози, як правило, не формуються [1]. При деструктивних формах кістозні порожнини виявляють у 30 \% хворих [2].

При лікуванні хворих із деструктивними формами панкреатиту необхідно передбачати профілактику формування псевдокіст. За даними літератури, етіологічними факторами гострого некротичного панкреатиту з подальшим формуванням псевдокіст у хворих є: зловживання алкоголем - 53 \%, біліарна патологія - 40 \%, травма - 6,7 \% [3]. У 6,1 \% випадків кісти виникають на тлі безсимптомних форм хронічного панкреатиту [4]. Важливим патогенетичним фактором розвитку ендотоксикозу $\epsilon$ активація процесів вільнорадикального окиснення. 3 одного боку, вільнорадикальне окиснення $€$ необхідною ланкою нормальної життєдіяльності організму; а з іншого - його порушення є раннім неспецифічним механізмом ушкоджень, які лежать в основі розвитку різних захворювань, у тому числі гострого і хронічного панкреатиту [5].

Зважаючи, що рівень антиоксидантної активності тканини підшлункової залози є одним з най- нижчих в організмі, то вивільнення у системний кровотік ендотоксинів і продуктів перекисного окиснення ліпідів, ймовірно, сприяє формуванню синдрому ендогенної інтоксикації [1]. Заслуговує на увагу оцінка ролі вільнорадикальних форм кисню у патогенезі постнекротичних кіст підшлункової залози. Активація процесів перекисного окиснення ліпідів $є$ універсальним, загальнобіологічним механізмом ушкодження клітин [5]. Однак виявлено, що до перекисного окиснення ліпідів особливо чутливі паренхіматозні органи $[5,6]$. Більшість авторів відносить підшлункову залозу до групи органів із низькою антиокисною активністю $[1,3]$. У патогенезі панкреонекрозу істотна роль відводиться змінам стаціонарного стану вільнорадикального окиснення й антиоксидантного захисту, проте у літературі недостатньо висвітлено питання про стан процесів ліпопероксидації та сполученої з нею антиоксидантної системи у хворих з постнекротичними кістами підшлункової залози.

Причина і умови формування псевдокіст підшлункової залози остаточно не визначені. На активацію процесів ліпопероксидації при панкреонекрозі вказують багато авторів [3, 7]. Про роль посилення процесів перекисного окиснення ліпідів і недостатність антиоксидантної системи у розвитку постнекротичних кіст підшлункової залози зустрічаються лише поодинокі повідомлення. У літературі недостатньо висвітлені дані про діагностичне значення вмісту у крові продуктів вільнорадикального окиснення при постнекротичних кістах підшлункової залози, немає інформації 
про можливості диференціальної діагностики, сформованість стінки псевдокісти на основі оцінки стану ліпопероксидації. Таким чином, процеси перекисного окиснення ліпідів та антиоксидантного захисту є маловивченою ланкою патогенезу псевдокіст.

Мета роботи: дослідити вміст псевдокіст підшлункової залози із подальшим аналізом стану вільнорадикальних процесів, що відбуваються.

Матеріали і методи. Представлені дані аналізу обстеження 90 пацієнтів. 3 них - 62 (68,9 \%) хворих із псевдокістами підшлункової залози. Було виділено чотири групи. Група А (порівняння) включала 12 (13,3 \%) осіб без патології

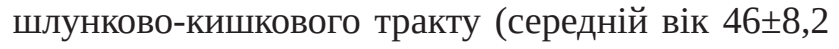
року). Групу В склали 18 (20 \%) хворих на хронічний панкреатит алкогольної етіології (середній вік 42,2 $\pm 7,4$ року). Групи С та D склали хворі 3 постнекротичними кістами підшлункової залози, 32 (35,6 \%) - 3 несформованими та 28 (31,1 \%) із сформованими відповідно. Середній вік хворих із постнекротичними кістами підшлункової залози склав $(46,4 \pm 11,6)$ року (від 18 до 78 років).

Серед хворих із псевдокістами підшлункової залози особи працездатного віку склали 84,3 \%, що зумовлює соціальну значущість проблеми. Розподіл захворюваності за статтю було наступним: 22 (36,7 \%) - жінки та 38 (63,3 \%) - чоловіків.

Основними причинами виникнення панкреонекрозу 3 наступним формуванням псевдокісти були жовчнокам'яна хвороба (33 \%) та вживання алкоголю (59 \%). Розміри псевдокіст варіювали від 10 до 170 мм і мали наступну локалізацію: головка підшлункової залози - 19 хворих (31,7 \%), тіло - 7 пацієнтів (11,6 \%), тіло з переходом на хвостовий відділ - 6 хворих (10 \%), хвостовий відділ - 28 пацієнтів (46,7 \%). У $4(6,7)$ пацієнтів (3 \%) визначення точної локалізації було ускладнено великим розміром псевдокісти - більше 170 мм.

Вміст малонового діальдегіду (МДА) оцінювали за кольоровою реакцією з 2-тіобарбітуровою кислотою у присутності трихлороцтової кислоти.
Вміст глутатіону визначали за методом Sedlak, Lindsey. Активність глутатіон-редуктази оцінювали за здатністю окиснювати НАДФН при довжині хвилі 340 нм. Активність глюкозо-6-фосфатдегідрогенази оцінювали за методикою Ю. Я. Захар’їна. Вміст сечової кислоти визначали за методом G. Oteta.

Результати досліджень та їх обговорення. МДА - токсичне з'єднання, що є вторинним продуктом процесів ліпопероксидації. Специфічність МДА полягає в тому, що він з'являється у надмірній кількості у крові та тканинах організму при виражених коливаннях вмісту кисню у ході метаболічних реакцій. Потужність антиоксидантної системи оцінювали за вмістом сечової кислоти та відновленого глутатіону, а також системи ферментів біорегенерації глутатіону: глутатіонредуктази та глюкозо-6-фосфатдегідрогенази. Зіставляючи дані про наявність ендогенної інтоксикації та інтенсифікації процесів ліпопероксидації, вивчено вміст про- та антиоксидантів у крові, а також у псевдокістах підшлункової залози залежно від ступеня їх сформованості (табл. 1).

Вміст МДА у плазмі крові та в еритроцитах у хворих із несформованими постнекротичними кістами підшлункової залози виявився достовірно вищим, ніж у групі хворих зі сформованими псевдокістами, а також у групі порівняння та у хворих із хронічним панкреатитом алкогольної етіології. У плазмі крові при несформованих псевдокістах вміст МДА на 26 \% перевищував аналогічний показник у групі контролю, на 18,3 \% - у групі з хронічним алкогольним панкреатитом і на 35,8 \% - при сформованих постнекротичних кістах. В еритроцитах вміст МДА перевищував контрольні значення при несформованих псевдокістах на 62,2 \%, у групі 3 хронічним алкогольним панкреатитом - на $37,5 \%$, при сформованих псевдокістах підшлункової залози - на 30,4 \%. Отже, при активному запальному процесі, що має місце при несформованих псевдокістах, визначається тенденція до накопичення МДА у периферійній крові цих хворих.

Таблиця 1. Вміст малонового діальдегіду в крові у хворих із постнекротичними кістами підшлункової залози (М土ó)

\begin{tabular}{||l|c|c|c|c||}
\hline \multicolumn{1}{|c|}{ Матеріал } & Група А & Група В & Група С & Група D \\
\hline Сироватка крові, ммоль/л & $6,34 \pm 0,17$ & $8,84 \pm 0,14$ & $10,38 \pm 0,21 *$ & $7,83 \pm 0,21 *$ \\
\hline Еритроцити, ммоль/л & $7,72 \pm 0,25$ & $11,63 \pm 0,28$ & $15,49 \pm 0,41 *$ & $12,24 \pm 0,43 *$ \\
\hline
\end{tabular}

Примітка. ${ }^{*}-\mathrm{p}<0,05$. 
Рівень відновленого глутатіону в еритроцитах виявився найнижчим у хворих на хронічний алкогольний панкреатит. У пацієнтів 3 несформованими постнекротичними кістами підшлункової залози вміст відновленого глутатіону був достовірно нижчим, ніж при сформованих постнекротичних кістах підшлункової залози, але вищим, ніж у хворих на хронічний алкогольний панкреатит (табл. 2).

Встановлено, що активність глутатіонредуктази у крові виявилася достовірно нижчою у хворих 3 несформованими постнекротичними кістами підшлункової залози, ніж у групі порівняння, у групі з хронічним алкогольним панкреатитом і у хворих зі сформованими псевдокістами. У хворих зі сформованими постнекротичними кістами підшлункової залози й хворих на хронічний алкогольний панкреатит достовірно значущих відмінностей активності глутатіонредуктази у сироватці крові не встановлено.

Також відзначено значне підвищення активності Г-6-ФДГ - основного ферменту пентозофосфатного циклу, що каталізує утворення відновлених еквівалентів, при несформованих постнекротичних кістах підшлункової залози у хворих зі сформованими псевдокістами підшлункової залози і хворих із хронічним алкогольним панкреатитом. Незважаючи на значний приріст активності Г-6-ФДГ, рівень відновленого глутатіону при несформованих псевдокістах залишався нижчим, ніж у групі порівняння та у хворих зі сформованими псевдокістами.

Вміст сечової кислоти в групі порівняння відповідав літературним даними, тоді як у плазмі кро- ві хворих із несформованими постнекротичними кістами підшлункової залози рівень сечової кислоти виявився достовірно нижчим, ніж у групі зі сформованими псевдокістами та у хворих на хронічний алкогольний панкреатит, але значно вищим, ніж у групі порівняння. Характерним було також те, що рівень сечової кислоти у хворих зі сформованими псевдокістами підшлункової залози виявився найвищим та перевищував цей показник як у групі хворих із несформованими псевдокістами підшлункової залози, так і у групі хворих з хронічним панкреатитом. Таким чином, вміст сечової кислоти у всіх хворих із псевдокістами підшлункової залози значно перевищував контрольні значення. Відзначено зворотну кореляційну залежність між вмістом МДА та глутатіону в еритроцитах.

Посилення процесів перекисного окиснення ліпідів при несформованих псевдокістах підшлункової залози відбувається на тлі пригнічення таких компонентів ендогенної антиоксидантної системи, як глутатіон та глутатіонредуктаза. Збільшення концентрації глутатіону та сечової кислоти при сформованих псевдокістах підшлункової залози у сукупності зі зниженням рівня МДА у плазмі та еритроцитах свідчить про зменшення функціонального напруження системи антиоксидантного захисту й стабілізацію процесів енергетичного метаболізму при формуванні стінки псевдокісти та локальному відмежуванні осередка запалення.

Проводили дослідження процесів ліпопероксидації безпосередньо у вмісті постнекротичних кіст підшлункової залози залежно від їх сформованості (табл. 3).

Таблиця 2. Дослідження факторів антиоксидантної активності хворих із постнекротичними кістами підшлункової залози

\begin{tabular}{||l|c|c|c|c||}
\hline \multicolumn{1}{|c|}{ Сироватка крові } & Група А & Група B & Група С & Група D \\
\hline Глутатіон еритроцитів, ммоль/л & $0,83 \pm 0,03$ & $0,72 \pm 0,11$ & $0,83 \pm 0,16^{*}$ & $1,29 \pm 0,16$ \\
\hline $\begin{array}{l}\text { Глутатіон редуктаза } \\
\text { еритроцитів, ммоль г/л }\end{array}$ & $0,65 \pm 0,05$ & $0,62 \pm 0,67$ & $0,39 \pm 0,13^{*}$ & $0,52 \pm 0,12 *$ \\
\hline Г-6-ФДГ, мкмоль г/л & $0,29 \pm 0,03$ & $1,56 \pm 0,12$ & $2,0992 \pm 0,173 *$ & $1,429 \pm 0,02 *$ \\
\hline Сечова кислота, мкмоль/л & $509,4 \pm 46,04$ & $1299,2 \pm 29,54$ & $949,7 \pm 29,43^{*}$ & $1702,0 \pm 59,3 *$ \\
\hline \hline
\end{tabular}

Примітка. ${ }^{*}-\mathrm{p}<0,05$.

Таблиця 3. Вміст малонового діальдегіду в псевдокістах підшлункової залози

\begin{tabular}{||c|c|c||}
\hline Дослідний показник & Несформовані псевдокісти & Сформовані псевдокісти \\
\hline МДА, ммоль/л & $5,02 \pm 0,34^{*}$ & $2,02 \pm 021^{*}$ \\
\hline
\end{tabular}

Примітка. * - відмінності достовірні р<0,01. 
У вмісті кіст встановлено пряму кореляційну залежність між рівнем глутатіону та МДА. При підвищенні концентрації МДА зростає концентрація антиоксидантів, достовірно збільшується вміст глутатіону та сечової кислоти. Вміст відновленого глутатіону в сукупності з підвищенням активності Г-6-ФДГ у несформованих псевдокістах свідчить про напругу ферментативної та неферментативної ланок антиоксидантної системи. Високий рівень антиоксидантів у ексудаті несформованих псевдокіст свідчить також про те, що тканини підшлункової залози залучені у запальний процес. Активація макрофагів під впливом TNF- $\alpha$ в осередку запалення супроводжується виробленням активних форм кисню та посиленням процесів ліпопероксидації, що, у свою чергу, викликає ушкодження клітинних структур тканини підшлункової залози. Токсична дія продуктів вільнорадикального окиснення сприяє підтримці запальної реакції та ішемії тканин у хворих із несформованими псевдокістами підшлункової залози. Виявлено пряму кореляційну залежність між вмістом МДА й олігопептидів у плазмі та в еритроцитах.

Таким чином, вираження активації вільнорадикальних реакцій зростала прямо пропорційно тяжкості ендогенної інтоксикації у хворих з псев- докістами підшлункової залози, що є одним з патогенетичних факторів захворювання.

Висновки. Однією з провідних ланок патогенезу формування ендогенної інтоксикації при постнекротичних псевдокістах підшлункової залози є інтенсифікація вільнорадикальних процесів на тлі недостатності антиоксидантної системи у поєднанні з накопиченням у рідких середовищах організму МДА та продуктів деградації білка олігопептидів. Висока інтенсивність вільнорадикальних процесів сприяє продукції надлишкової кількості прозапальних цитокінів та гіперімуноглобулінемії, що зумовлює хронізацію запального процесу та наростання тяжкості ендогенної інтоксикації. Дослідження вмісту псевдокіст дало змогу визначити стан вільнорадикальних процесів у ньому і виявило високу токсичність ексудату при несформованих псевдокістах. Критеріями несформованості стінки псевдокісти є підвищення вмісту МДА в еритроцитах крові хворих.

Перспективи подальших досліджень. Подальші дослідження будуть спрямовані на ретельніше вивчення вмісту в крові продуктів вільнорадикального окиснення при постнекротичних кістах підшлункової залози.

\section{СПИСОК ЛІТЕРАТУРИ}

1. The revised Atlanta criteria more accurately reflect severity of post-ERCP pancreatitis compared to the consensus criteria / X. Smeets, N. Bouhouch, J. Buxbaum [et al.] // United European Gastroenterol. J. - 2019. - Vol. 7 (4). - P. 557-564.

2. Криворучко И. А. Дифференцированный подход к выбору метода лечения псевдокист поджелудочной железы / И. А. Криворучко // Клінічна хірургія. - 2013. - № 7. - С. 1619.

3. A population-based evaluation of the natural history of chronic pancreatitis / J. D. Machicado, S. T. Chari, L. Timmons [et al.] // Pancreatology. - 2018. - Vol. 18 (1). - P. 39-45.

4. Clinical practice guideline: management of acute pancreatitis

/ J. A. Greenberg, J. Hsu, M. Bawazeer [et al.] // Can. J. Surg. 2016. - Vol. 59 (2). - P. 128-140.

5. Adams D. B. Pancreatitis: medical and surgical management / D. B. Adams. - Chichester: Wiley Blackwell, 2017. - 326 p.

6. Plasma cytokines can help to identify the development of severe acute pancreatitis on admission / L. H. Deng, C. Hu, W. H. Cai, [et al.] // Medicine (Baltimore). - 2017. - Vol. 96 (28). - P. e7312.

7. Role of NO synthases deficiency in the development of pancreatitis (experimental study) / O. Krylova, N. Gubergrits, A. Rudenko [et al.] // Pancreatology. - 2019. - Vol. 19 (1). P. S25-S26.

\section{REFERENCES}

1. Smeets, X., Bouhouch, N., Buxbaum, J., Zhang, H., Cho, J., Verdonk, R.C., ..., \& van Geenen, E. (2019). The revised Atlanta criteria more accurately reflect severity of post-ERCP pancreatitis compared to the consensus criteria. United European Gastroenterol. J., 7 (4), 557-564. DOI: 10.1177/2050640619834839. 2. Krivoruchko, I.A. (2013). Differentsirovannyiy podhod k vyiboru metoda lecheniya psevdokist podzheludochnoy zhelezy [Differentiated approach to the choice of treatment for pancreatic pseudocysts]. Klinichna khirurhiia - Clin. Surg., 7, 16-19 [in Ukrainian].

3. Machicado, J.D., Chari, S.T., Timmons, L., Tang, G., \& Ya-

dav, D. (2018). A population-based evaluation of the natural history of chronic pancreatitis. Pancreatology, 18 (1), 39-45. DOI: 10.1016/j.pan.2017.11.012.

4. Greenberg, J.A., Hsu, J., Bawazeer, M., Marshall, J., Friedrich, J.O., Nathens, A., . .., \& McLeod, R.S. (2016). Clinical practice guideline: management of acute pancreatitis. Can. J. Surg., 59 (2), 128-140. DOI: 10.1503/cjs.015015.

5. Adams, D.B. (2017). Pancreatitis: medical and surgical management. Chichester: Wiley Blackwell. 326 p.

6. Deng, L.H., Hu, C., Cai, W.H., Chen, W.W., Zhang, X.X., Shi, N., ..., \& Xia, Q. (2017). Plasma cytokines can help to 
identify the development of severe acute pancreatitis on admission. Medicine (Baltimore), 96 (28), e7312. DOI: 10.1097/ MD.0000000000007312.
7. Krylova, O., Gubergrits, N., Rudenko, A., Haydar, Y., Karachynova, V. (2019). Role of NO synthases deficiency in the development of pancreatitis (experimental study). Pancreatology, 19 (1), S25-S26. DOI: 10.1016/j.pan.2019.05.059.

Електронна адреса для листування: batsmannazariy@gmail.com

V. V. BOYKO 1,2 , V. M. LYKHMAN ${ }^{1,3}$, S. V. TKACH' ${ }^{1}$, O. M. SHEVCHENKO ${ }^{2}$, D. O. MIROSHNICHENKO², A. O. MERKULOV ${ }^{1}$, K. M. YATSKO ${ }^{1}$, E. O. BELODED ${ }^{2}$, N. V. BATSMAN ${ }^{2}$

V. Zaytsev Institute of General and Urgent Surgery, National Academy of Medical Sciences of Ukraine ${ }^{1}$ Kharkiv National Medical University²

Kharkiv Medical Academy of Postgraduate Education ${ }^{3}$

\section{ANALYSIS OF THE STATE OF LIPOPEROXIDATION PROCESSES DEPENDING ON THE FORMATION OF POSTNECROTIC CYST OF THE PANCREAS}

The aim of the work: to investigate the content of pancreatic pseudocysts with further determination of the state of free radical processes in it.

Materials and Methods. The data of the analysis of examination of 62 patients with pancreatic pseudocysts are presented. The prooxidant-antioxidant balance in the blood and in the content of pancreatic pseudocysts was studied, depending on the degree of formation of the cystic wall.

Results and Discussion. The study of the content of pancreatic pseudocysts made it possible to determine the state of free radical processes in it and revealed a high toxicity of exudate in unformed pseudocysts. The marker of the imperfection of the pseudocyst wall is the increased content of malondialdehyde in the erythrocytes of the patients' blood.

Key words: pancreatic necrosis; pancreatic pseudocyst; lipid peroxidation. 